\title{
PARACOCCIDIOIDOMYCOSIS: A SEQUENTIAL HISTOPATHOLOGIC STUDY OF LESIONS IN EXPERIMENTALLY-INFECTED RATS
}

\author{
I.B. KERR (1), J.R. ARARIPE (1,3), P.C. OLIVEIRA (2) \& H.L. LENZI (1)
}

\begin{abstract}
SUMMARY
Female albino rats were used for the sequential histopathological study of experimental paracoccidioidomycosis. The animals were inoculated intraperitoneally with a strain of Paracoccidioides brasiliensis in the yeast-like phase, and sacrificed at given intervals from 1 to 168 days after inoculation; each animal received an inoculum of $4 \times 10^{6}$ cells in $0.8 \mathrm{ml}$ of saline. The control group received saline containing scrapings of the culture medium:

Tissue from the inoculation site was examined. The cellular population, the extracellular matrix, and the presence and characteristics of fungi were analysed in the inflammatory granulomatous process by light microscopy.

The results allowed to separate the kinetic of the inflammatory response into three stages: 1) neutrophilic or macrophagic-neutrophilic; 2) pre-granulomatous; 3 ) granulomatous.

Synthesis of the extracellular matrix began with the depositing of fibrin-like material, and increased gradually with deposits of collagen, proteoglycans, and glycoproteins. Parasites were present in all of the examined periods.

Recurrences of the disease were clearly shown through the concurrence of recently-formed granulomas with older granulomas, implying that this type of granulomatous process does not eliminate the disease, nor is it able to limit fungal dissemination over a prolonged period of time.
\end{abstract}

KEY WORDS: Paracoccidioidomycosis; Paracoccidioides brasiliensis; Granuloma; Extracellular matrix; Collagen; Proteoglycans.

\section{INTRODUCTION}

Paracoccidioidomycosis, caused by Paracoccidioides brasiliensis is a deep mycosis, endemic in Latin America.

Most of the studies on the pathology of paracoccidioidomycosis are based on the examination of human material collected in biopsies of variously-located lesions, or in the examination of necropsies, with both situations representing only a specific stage of the disease. Furthermore, this mycosis usually develops slowly, asymptomatically, and at times with long incubation periods, so that when the patient solicits medical treatment, the lesions are already well established and have had variable periods of development. On the other hand, the lack of precise information on the ecology of the fungus, doubts as to the portal of entry, and, therefore, the absence of studies

(1) Department of Pathology of the Instituto Oswaldo Cruz, Fundaçåo Oswaldo Cruz, Rio de Janeiro, RJ., Brazil.

(2) Department of Mycology of the Instituto Oswaldo Cruz, Fundaçao Oswaldo Cruz, Rio de Janeiro, RJ., Brazil.

(3) Recipient of a CNPq Fellowship (N: 822868-86.5)

Address for correspondence: Itália B. Kerr, Departamento de Patologia, Instituto Oswaldo Cruz, FIOCRUZ. Caixa Postal 926. CEP 20010 Rio de Janeiro, RJ, Brasil. 
KERR, I.B.; ARARIPE, J.R.; OLIVEIRA, P.C. \& LENZI, H.L. - Paracoccidioidomycosis: a sequential histopathologic study of lesions in experimentally-infected rats. Rev. Inst. Med. trop. Sao Paulo, 30(5):336-350, 1988.

on lesions at the initial stages of human infection, have hampered a systematic study of the pathology, and a correlation between the pattern of lesions and the clinical forms of the disease.

Experimental studies have provided important information in the explanation of various aspects of the disease, and their advantage is allowing one to follow the disease since its early stages. These studies are possible because laboratory animals, such as hamsters, mice, guinea pigs, and rats, are susceptible to infection, although with different characteristics ${ }^{6,25,26,30,34}$. TEIXEIRA et al. ${ }^{34}$ and KERR et al. ${ }^{21,22}$, for example, showed that in the albino rat, intraperitoneal inoculation of a high concentration of fungus can cause a chronic, progressive, and generalized infection such as in humans, and that under the same conditions, females are more sensitive to the disease.

In spite of the many experimental studies conducted in the last few years, few have focused on the study of paracoccidioidomycotic granuloma. Thus, our present and main purpose is a kinetic study of the granuloma through the course of infection, by analysing the role of cellular elements and components of the extracellular matrix.

\section{MATERIAL AND METHODS}

\section{Animals}

Forty-five, two-month-old female albino rats, weighing on average $120 \mathrm{~g}$, obtained from the animal colony of the Instituto Oswaldo Cruz, were used in this experiment.

\section{Fungus and inoculum}

$\mathbf{P}$. brasiliensis (strain 28 , originally obtained from the culture collection of the Mycology Laboratory, Instituto de Pesquisas Gonzaga da Gama Filho, maintained at the Mycology Department of the Instituto Oswaldo Cruz), was used in the yeast phase, cultured on brain heart infusion agar (Difco) at $36^{\circ} \mathrm{C}$.

For the challenge inoculum; yeast cells were harvested from three-day-old cultures, suspended in sterile normal saline and centrifuged. The cell pellets were washed once and resuspended in saline.

Viability of cells was $80 \%$, as assessed by methylene blue, neutral red and Janus green stains. Total cell counts in a hemocytometer chamber were used to estimate the inoculum size and adjusted to approximately $4 \times 10^{6}$ cells $/ 0.8 \mathrm{ml}$ of saline for each animal.

\section{Experimental procedure and morphological examinations}

Thirty-nine rats were intraperitoneally infected with the inoculum and six received, by the same via, an equal volume of a solution of saline with a few scrapings of the culture medium.

The animals were sacrificed according to the experimental protocol (Table 1).

At necropsy, tissue samples were taken from the epiploon, mesentery, peri-pancreatic, peri-splenic and peri-renal areas, corresponding to the inoculation site.

For light microscopy, the specimens were fixed in Millonig's formalin 10 , in an average $\mathrm{pH}$ ranging between 7.0 and 7.4 , and embedded in

TABLE 1

EXPERIMENTAL PROTOCOL

\begin{tabular}{|c|c|c|c|c|c|c|c|c|c|c|c|c|c|c|}
\hline \multirow{2}{*}{ Groups } & \multicolumn{14}{|c|}{ Days after inoculation * } \\
\hline & 1 & 2 & 3 & 7 & 10 & 14 & 21 & 28 & 42 & 49 & 63 & 112 & 168 & Total \\
\hline $\begin{array}{l}\text { Infected rats } \\
\text { Non - infected rats (Control group) }\end{array}$ & $\begin{array}{l}3 \\
1\end{array}$ & 3 & $\begin{array}{l}3 \\
1\end{array}$ & $\begin{array}{l}3 \\
1\end{array}$ & $\begin{array}{l}3 \\
-\end{array}$ & $\begin{array}{l}3 \\
1\end{array}$ & $\begin{array}{l}3 \\
-\end{array}$ & 3 & $\begin{array}{l}3 \\
-\end{array}$ & 3 & 3 & $\begin{array}{l}3 \\
-\end{array}$ & $\begin{array}{l}3 \\
1\end{array}$ & $\begin{array}{c}39 \\
6\end{array}$ \\
\hline
\end{tabular}

* The number of days represents time elapsed between inoculation of the fungus and sacrifice of the animals. 
KERR, I.B.; ARARIPE, J.R.; OLIVEIRA, P.C. \& LENZI, H.L. - Paracoccidioidomycosis: a sequential histopathologic study of lesions in experimentally-infected rats. Rev. Inst. Med. trop. São Paulo, 30(5):336-350, 1988.

paraffin. Sections were stained by the following methods: hematoxylin and eosin (HE); Grocott's methenamine-silver nitrate technique (Grocott), for identification of fungi; periodic acid-Schiff (PAS) reaction for glycoproteins; PAS-Alcian blue (PAS-AB), $\mathrm{pH} 1.0$ and 2.5, for demonstrating sulfated and acid proteoglycans; Lennert's Giemsa, for cellular characterization24; Weigert's resorcin-fuchsin for elastic fibers; Masson's trichrome, Gomori's silver reticulin and picrosirius (plus polarization microscopy), for identification of collagen I and III'19. In fact, by this method, collagen type I appears as strongly birefringent, yellow or red fibers; whereas collagen type III appears as weakly birefringent greenish fibers.

\section{RESULTS}

\section{Macroscopy}

The animals did not show changes at the macroscopic level up to the $7_{\text {th }}$ day after inoculation, but an edematous and congested appearance was observed in the tissue of the inoculation site. From the $10^{\text {th }}$ day on lesions were observed in the area of the pancreas, epiploon, spleen capsule, inner side of the peritoneal cavity, and phrenic center. The lesions were characteristically nodular and punctiform. After these stages on, in some animals, there were pseudo-tumoral masses consisting of confluent nodules, with granular surface, occupying the epipioon or the frontal abdominal region.

\section{Histopathology}

On day one, the mesenterium showed an exudative reaction with numerous neutrophils surrounding degenerated fungi and fungal debris. Monocytes, lymphocytes, eosinophils, degranulating mast cells and clumps of macrophages were also present.

Milky-spots showed increases in vascular network and cellularity, due mainly to monocytes and mesothelial reactivity.

At 2 and 3 days the neutrophils and degenerated fungi decreased in the lesions. The expressive event was the first delineation of granulomas characterized by clumps of macrophages in early maturation stage and occasional presence of epithelioid cells and giant cells: Surrounding the granulomas, there was a proliferation of fibroblasts, appearance of the first plasma cells, increase in the influx of lymphocytes and presence of transformed lymphocytes, with features of immunoblasts or lymphoblast-like cells.

The migration of mesothelial cells to the vicinity of the inflammatory foci (mesothelial dropping) began at this stage of infection.

On the $7^{\text {th }}$ day, the main feature. was the presence of definitive granulomas, consisting of compact aggregates of mature macrophages, epithelioid cells, giant cells, higher number of plasma cells and intense monocytic mobilization in their periphery.

By the $10^{\text {th }}$ day postinoculation, the most important change was the structural zoning of the granulomas, expressed by a central zone (parasite-macrophagic) with or without necrosis surrounded by a peripheral zone, consisting of fibroblast-like cells (fibroblastoid). Eosinophils and mast cells inside the granulomas were also noticed.

Between the days 14 and 63 , the granulomas showed different stages of development, with gradual decrease of nitonocytic mobilization and lymphocytic transformation. Small lymphocytes and plasma cells predominated in the outer layer, and giant cells decreased in number and sometimes were detected isolatelly, not taking part of the granuloma structure. Mast cells showed variation in number and in the process of degranulation.

From the 63rd day till the end of the experiment, occurred reactivation of the disease expressed by the simultaneous presence of incipient and old granulomas (Fig. 1). Plasma cells were prominent and proliferation of fibroblastic cells was constant and intense. By the $168^{\text {th }}$ day appeared large foci of granulomatous reaction centered by collagen fibers replacing previous necrotic zone (postnecrotic healing).

On 14, 49, 63 and 112 days, some peritoneal nodules exhibited granulomas with intrinsic vascularization, represented by intense angiogenesis, forming capillaries in their peripheral layer (Fig. 2).

Components of the extracellular matrix began to appear after 1 day of infection readily identified as fibrin like material in the serosa, blood vessels and around the inflammatory infiltrate. Acid proteoglycans were also 
KERR, I.B.; ARARIPE, J.R.; OLIVEIRA, P.C. \& LENZI, H.L. - Paracoccidioidomycosis: a sequential histopathologic study of lesions in experimentally-infected rats, Rev. Inst. Med, trop. São Paulo, 30(5):336-350, 1988.

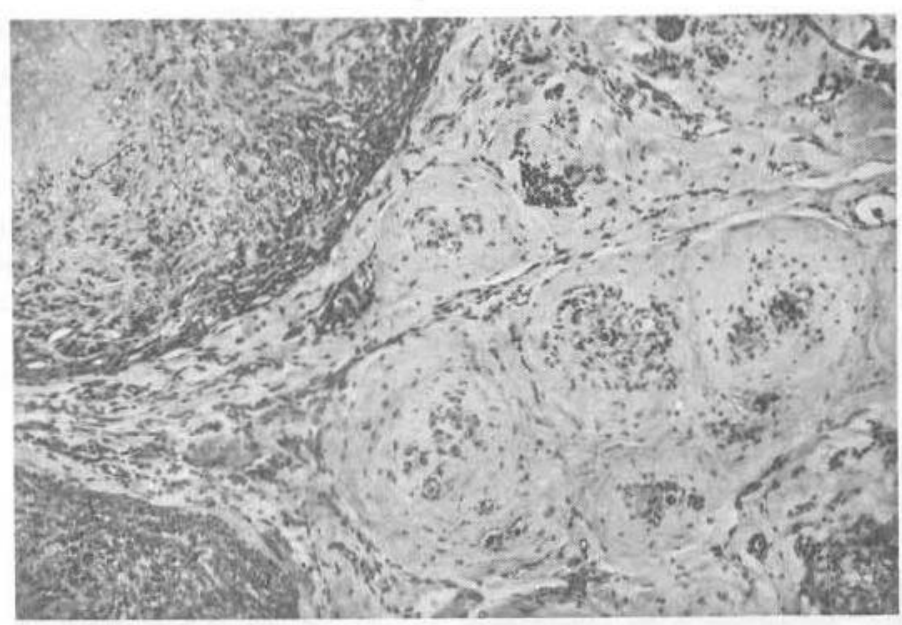

Fig. 1 - Active granulomatous foci, one of them centered by necrosis, close to fibrotic granulomas. (168 days). Hematoxylin and eosin, $x 80$.

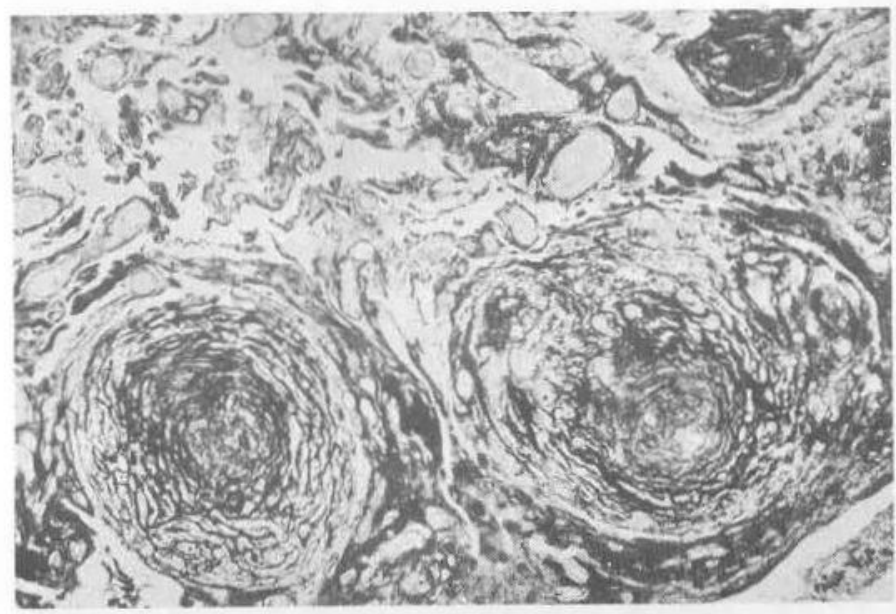

Fig. 2 - Granulomas with external layer intensely vascularized by neo-angiogenesis and congestion of the contiguous vessels. (49 days). Picrosirius, $x 80$.

observed surrounding the areas rich in parasites.

On the $7^{\text {th }}$ day, a net-like pattern of thin reticular fibers were visible with Gomori's silver-reticulin technique among the inflammatory focuses and even inside the granulomas. These fibers were not positive by the Picrosirius-polarization method. Collagen fibers of type III and acid proteoglycans were found around the granulomas.

On the $10^{\text {th }}$ day, collagen fibers of type I and III were concentrically deposited in the peripheral zone of the granulomas along with sulfated proteoglycans. Acid proteoglycans were identified in the granulomas on the $14^{\text {th }}$ day.

After 21 days, the structural demarcation of the granulomas was well defined by the matrix, and the following 3 zones were more apparent: 1) central zone, without collagen; 2) paracentral zone, with fibroblastic-like cells; 3 ) peripheral zone, forming a fibrotic capsule-like structure. At the interface between the central and paracentral zones, sometimes appeared a 
KERR, I.B.; ARARIPE, J.R.; OLIVEIRA, P.C. \& LENZI, H.L. - Paracoccidioidomycosis: a sequential histopathologic study of lesions in experimentally-infected rats. Rev. Inst. Med. trop. São Paulo, 30(5):336-350, 1988.

band of collagen, mainly of type I, connected by radiated fibers to the external capsular zone (Fig. 3).

Synthesis of the extracellular matrix was constant between days 28 and 42 ; however, the greater number of reticular fibers in relation to collagen fibers in the granulomas' central region was conspicuous (Fig. 4).

From the $4^{\text {th }}$ day on, the collagen type I was predominant in the granulomas.
At days 112 and 168 there was a reversal in the fibrillar pattern of the granulomas, with a marked decrease in reticular fibers and increase in collagen, especially of type I. However, deposits of collagen fibers of type III and of sulfated proteoglycans remained constant, and acid proteoglycans were strongly stained in post-necrotic healing areas and in calcification foci.

The presence of positive PAS material in

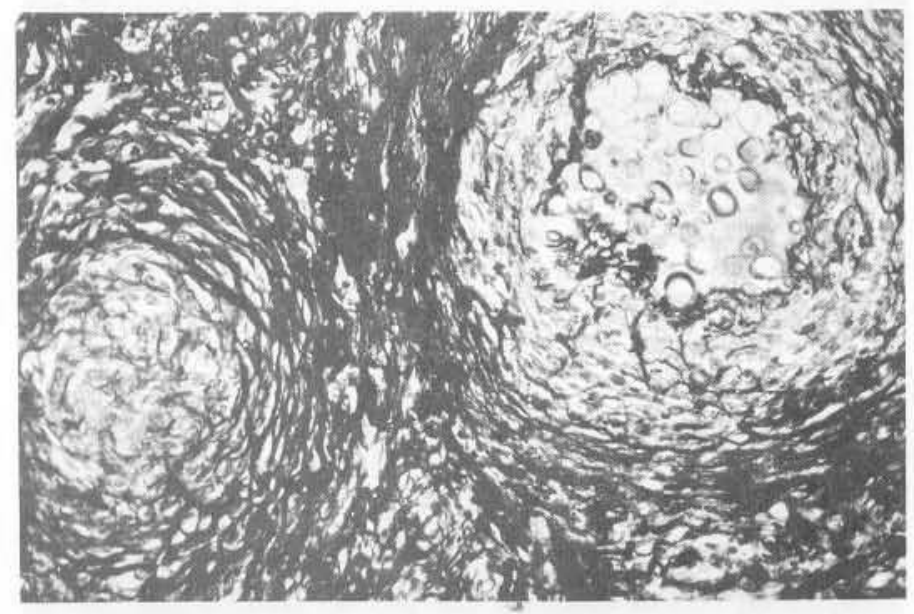

Fig. 3 -Distribution of collagen, especially of type 1 , in the various zones of the granuloma. Granuloma on the right shows a fibrotic band in the interface between the central and paracentral zones. (21 days). Picrosirius, x 200.

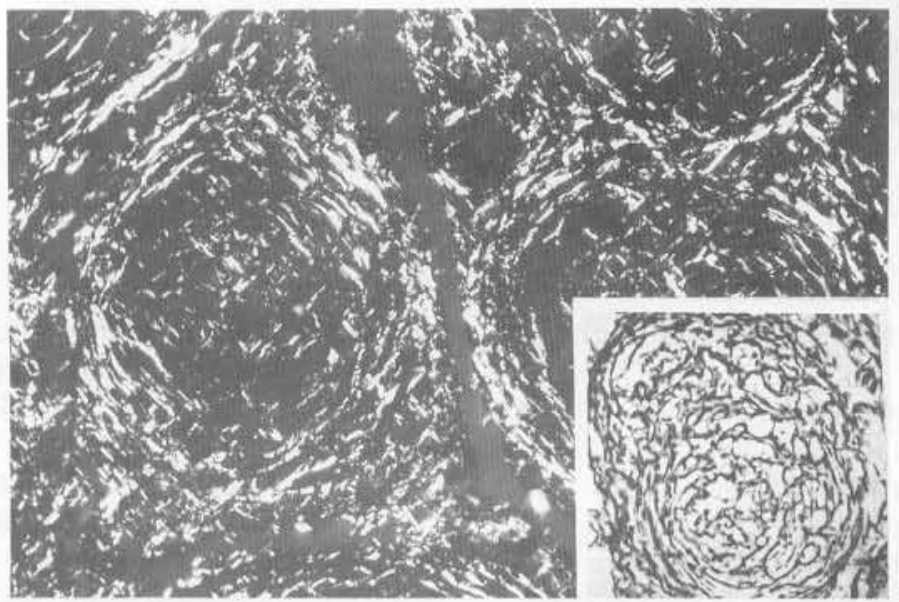

Fig. 4-Predominance of reticular fibers in relation to collagen fibers in the central and paracentral regions of the granulomas. (28 days). Picrosirius polarized light, x 200. Insert, Gomori's silver reticulin, x 200. 
KERR, I.B.; ARARIPE, J.R.; OLIVEIRA, P.C. \& LENZI, H.L. - Paracoccidioidomycosis: a sequential histopathologic study of lesions in experimentally-infected rats. Rev. Inst. Med. trop. Sie Paulo, 30(5):336-350, 1988.

the ground substance was a constant through the course of infection, and increased on day $6^{\text {th }}$ especially in areas of intense collagenesis. The granulomas did not contain elastic fibers at any of the stages.

The fungi were present in tissue in great amount during the first 2 days of infection, circumscribed by neutrophilic inflammatory infiltrate. Many of them were only represented by empty and deformed cells or fragments of cell walls, showing signs of degeneration. Nevertheless, some fungi persisted in the budding form.

While the neutrophilic inflammatory infiltrate was being substituted by the monocytic-macrophagic infiltrate, parasite degeneration decreased, budding remained constant, and they were found mainly inside the giant cells of the granulomas. Starting on the $14^{\text {th }}$ day and especially on the $28^{\text {th }}$ day, P. brasiliensis began to multiply intensively, so that no dust representative of degenerated parasites could be found.

A more vivid global and kinetic picture of lesions development can be given by figures 5 (cellular elements), 6 (components of the extracellular matrix), and 7 (parasite-related aspects).

Granulomatous reactions were not seen at any moment in the control group animals; only a reactivity of milky-spots was observed at the first days.

\section{DISCUSSION}

Our histopathologic findings correspond to those of other authors who studied the sequential form of experimental paracoccidioidomycosis ${ }^{17,29,30}$, although these studies used different experimental models. Using intraperitoneally-inoculated rats, we observed that both cellular and extracellular matrix components present during the inflammation were temporary elements which fluctuated in their role in the host's response to $P$. brasiliensis through the course of infection. Based on the results, we were able to divide the inflammatory process into 3 reasonably distinctive sequential stages: 1) neutrophilic or monocytic-neutrophilic stage (1 day after inoculation); 2) pre-granulomatous stage (days 2 and 3); and 3) granulomatous stage (starting day 7) (Figs. 8, 9 and 10).
During the neutrophilic stage, the cells might have been attracted initially by chemotactic factors released by the parasites themselves or proceeding from the plasma or from other cells, direct or indirectly stimulated by parasitic factors ${ }^{8,9}$. The presence of mast cells could also exert a strong influence on chemotactic mechanisms for neutrophilic and macrophages ${ }^{33}$.

Although RESTREPO \& VÉLEZ 32 showed that neutrophils in patients with paracoccidioidomycosis kill $\mathbf{P}$. brasiliensis in vitro, the fungicidal activity of neutrophils in peripheral blood is still uncertain. McEWEN et al.27 studied the influence on fungi of polymorphonuclear leukocytes from peripheral blood and the peritoneal cavity, and showed in vitro that the neutrophils possessed excellent fungicidal activity when obtained from mice sensitized with the homologous antigen, and that the complement system played an important role in this process.

There seems to be a relationship between destruction of fungi by neutrophils and the latter's ability to produce an increased oxidative burst. Toxic oxygen metabolites are pointed out as one of the mechanisms responsible for the killing of $\mathbf{P}$. brasiliensis in the $\mathrm{H}_{2} \mathrm{O}_{2}$-halide-peroxidase system 28 .

In spite of these findings, GOIHMAN. YAHR et al. 16 noticed in similar in vitro studies that polymorphonuclear leukocytes from patients with paracoccidioidomycosis, phagocytised fungi in a normal manner, but had a low capacity to digest them. These authors also demonstrated that the fungal strain's pathogenicity was indirectly proportional to its susceptibility to in vitro digestion by the neutrophil.

Our findings show that in spite of the large quantities of neutrophils at the onset of infection, they were not able to kill all of the fungi. Since the parasites were not completely eliminated, there was a change in the host's response pattern, with a subsequent substitution of the polymorphonuclear for mononuclear phagocytes.

Lymphocytes in the first stage might have been sensitized by fungal antigens, thus releasing lymphokines which would cause an increased influx of mononuclear cells to the inflammation site, and their activation.

When the neutrophilic stage ended, many granulomas were developing in the areas 
KERR, I.B.; ARARIPE, J.R.; OLIVEIRA, P.C. \& LENZI, H.L. - Paracoccidioidomycosis: a sequential histopathologic study of lesions in experimentally-infected rats. Rev. Inst. Med. trop. S*o Paulo, 30(5):336-350, 1988.

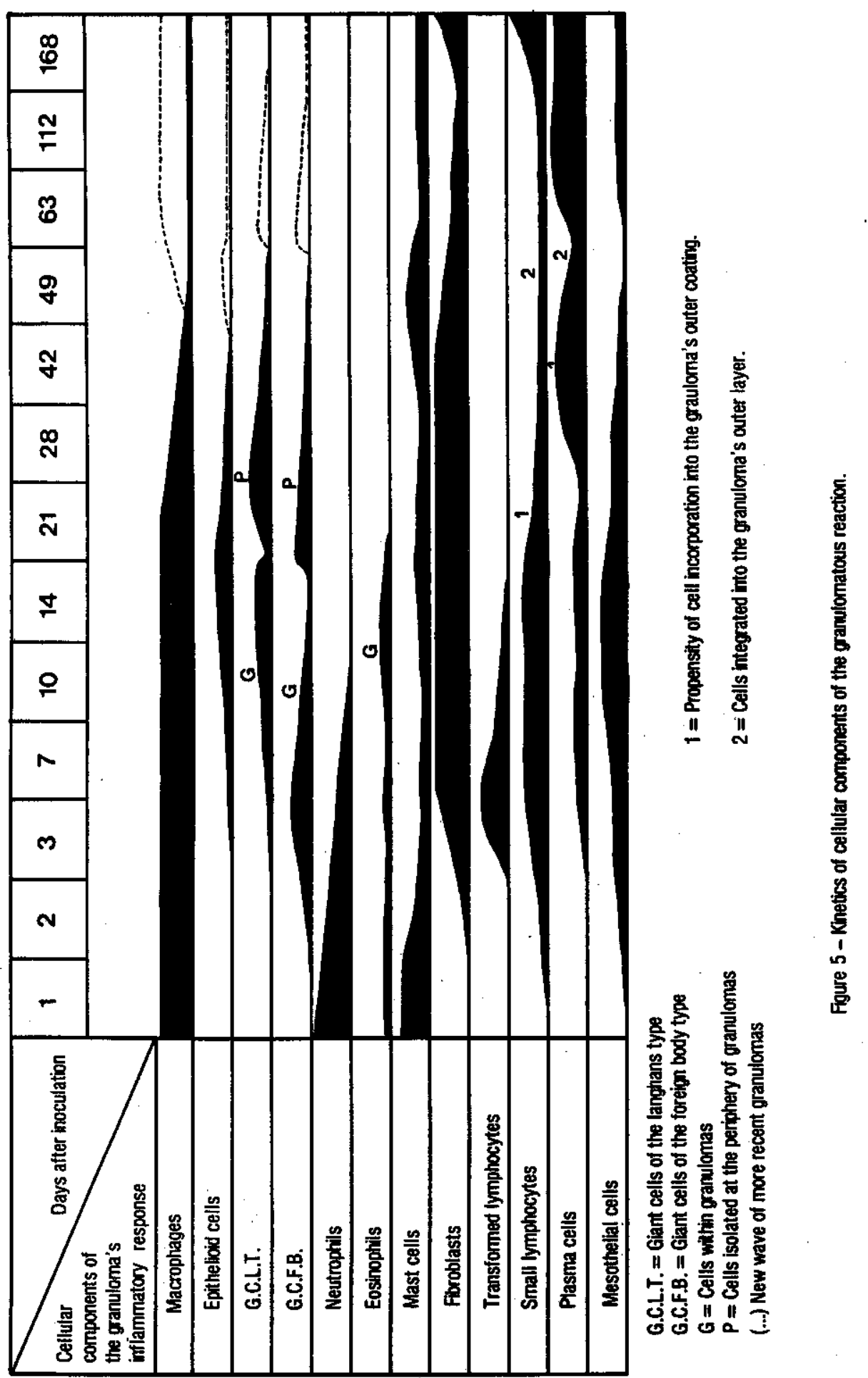


KERR, I.B.; ARARIPE, J.R.; OLIVEIRA, P.C. \& LENZI, H.L. - Paracoccidioidomycosis: a sequential histopathologic study of lesions in experimentally-infected rats. Rev. Inst. Med. trop. Sfo Paulo, 39(5):336-350, 1988.

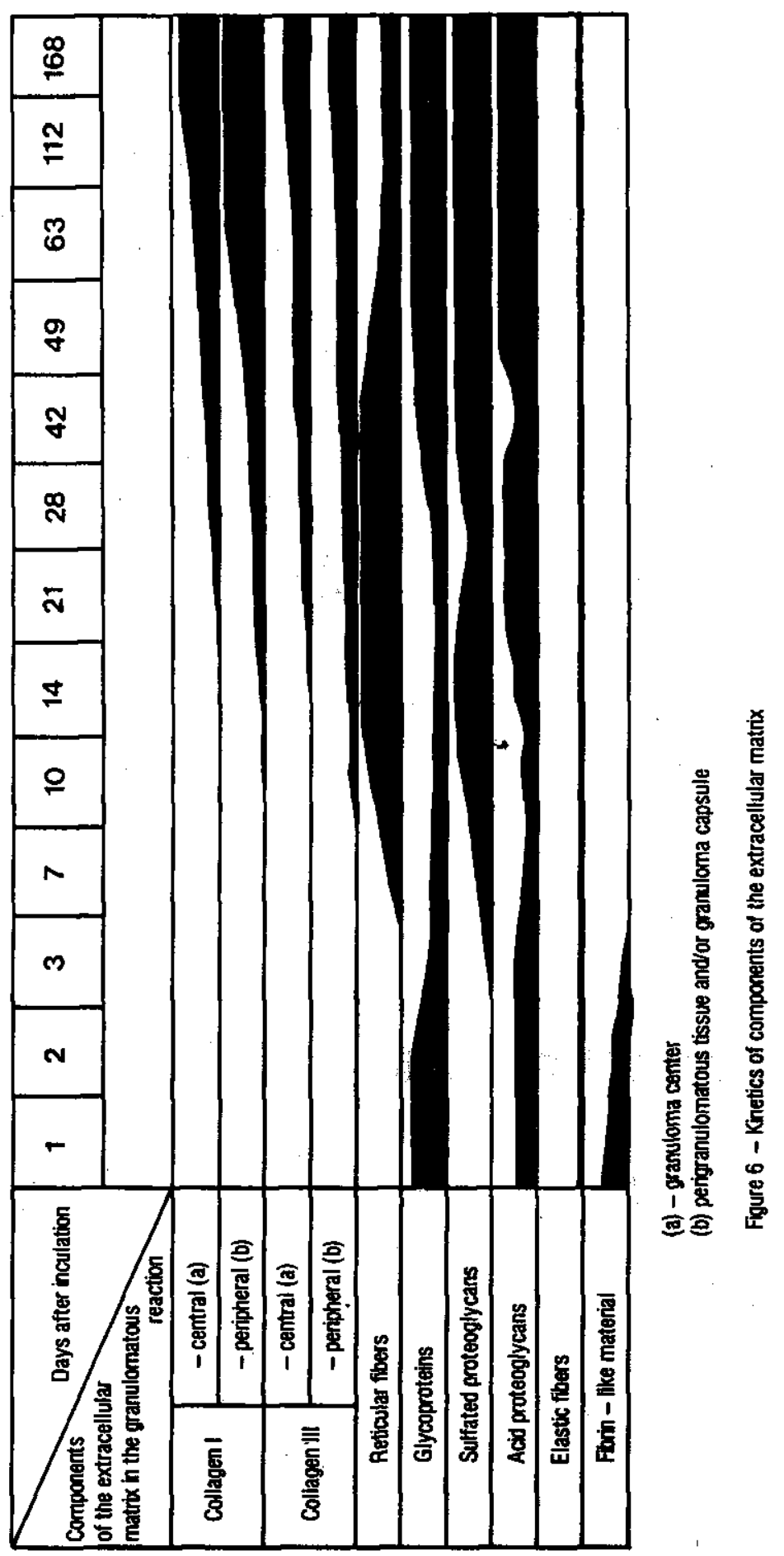


KERR, I.B.; ARARIPE, J.R.; OLIVEIRA, P.C. \& LENZI, H.L. - Paracoccidioidomycosis: a sequential histopathologic study of lesions in experimentally-infected rats. Rev. Inst. Med. trop, Säo Paulo, 30(5):336-350, 1988.

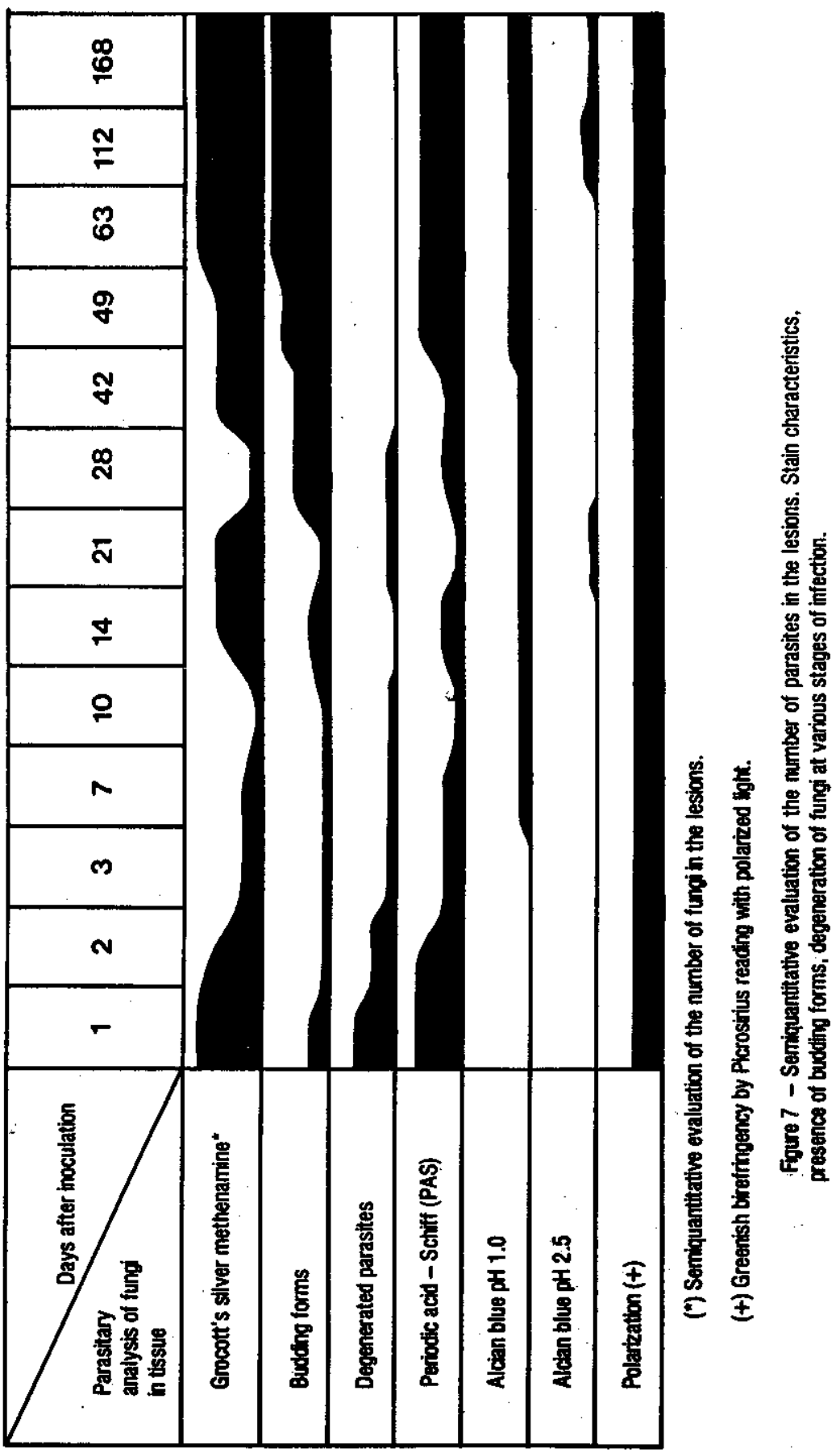


KERR, I.B.; ARARIPE, J.R.; OLIVEIRA, P.C. \& LENZI, H.L. - Paracoccidioidomycosis: a sequential histopathologic study of lesions in experimentally-infected rats. Rev, Inst. Med. trop. Swo Paulo, 30(5):336-350, 1988.

corresponding to milky-spots, indicating that these structures would play an important defensive role in the peritoneal infection by $\mathbf{P}$. brasiliensis 1 .

During the pre-granulomatous stage, macrophagic cells were acquiring an organized pattern, leaning towards a certain degree of maturity, while the neutrophilic exudate diminished. These cellular arrangements were termed pre-or incipient granulomas, because they presented an initial formation of giant cells of the foreign body type and because of the presence of the first epithelioid-type cells. At this pre-granulomatous stage, the lymphocytes were active or transformed, as shown by the morphologic characteristics of their lymphoblast-like and immunoblast-like cells. Lymphokines could be acting on the macrophages, stimulating their maturity 35 , and influencing the fibroblasts through the Fibroblast Activating Factor (FAF) and Fibroblast Chemotactic Factor (FCF) ${ }^{36}$.
Activated macrophages could also be releasing FCF, FAF, and the Fibroblast Growth Factor (FGF), along with Interleukin-1, augmenting proliferation and synthesis in the matrix at the inflammatory site15.36. During this stage, mesothelial cells could be under the chemotactic influence of some factor secreted by inflammatory cells at the site of the lesions, possibly secreted by the macrophages ${ }^{38}$.

At the granulomatous stage, the granulomas were well defined, and gradually showed structural zoning. We used the term fibroblastoid in the paracentral zone of the granulomas because, by the light microscopy, macrophages, myofibroblasts, endothelial cells, and fibroblasts can all display a spindleshaped form.

The presence of isolated giant cells in extra-granulomatous areas was interpreted in two ways: they could be residual giant cells which had become more apparent with the regression of the other components of the

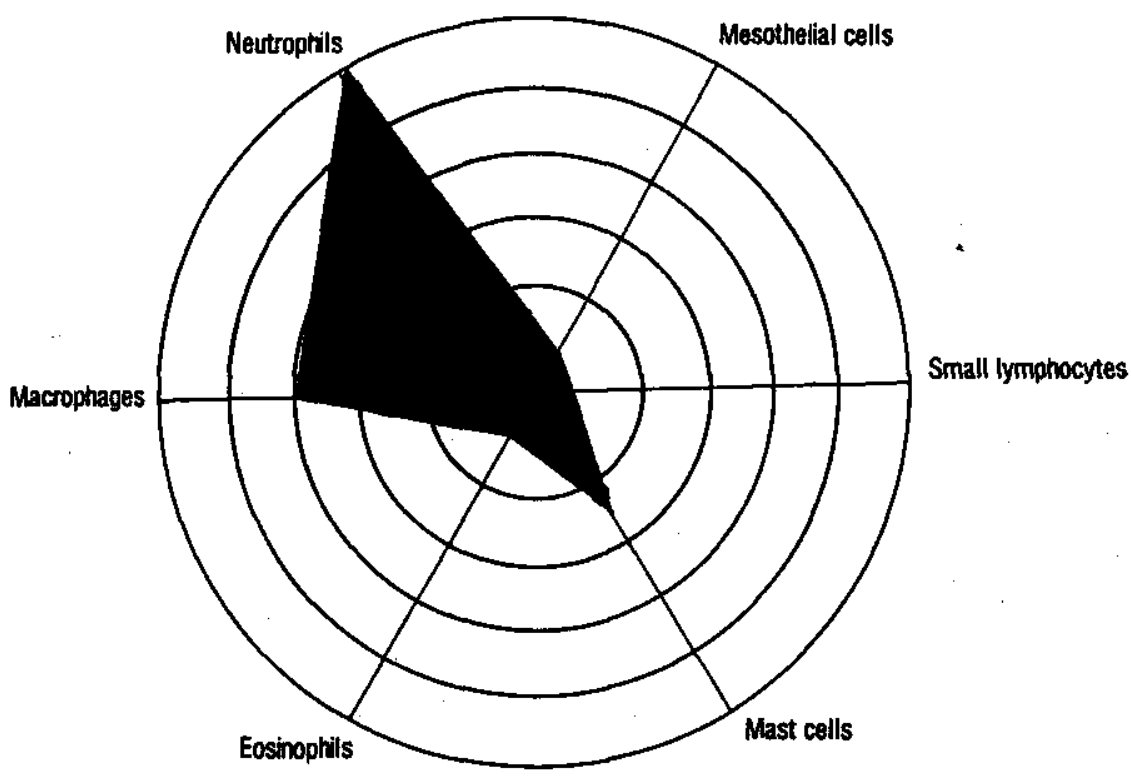

Figure 8 - Schematic of the presence of major cellutar elements at the neutrophilic or macrophagicneutrophilic stage of infection. 
KERR, I.B.; ARARIPE, J.R.; OLIVEIRA, P.C. \& LENZI, H.L. - Paracoccidioidomycosis: a sequential histopathologic study of lesions in experimentally-infected rats. Rev. Inst. Med. trop. Sxo Paulo, 30(5):336-350, 1988.

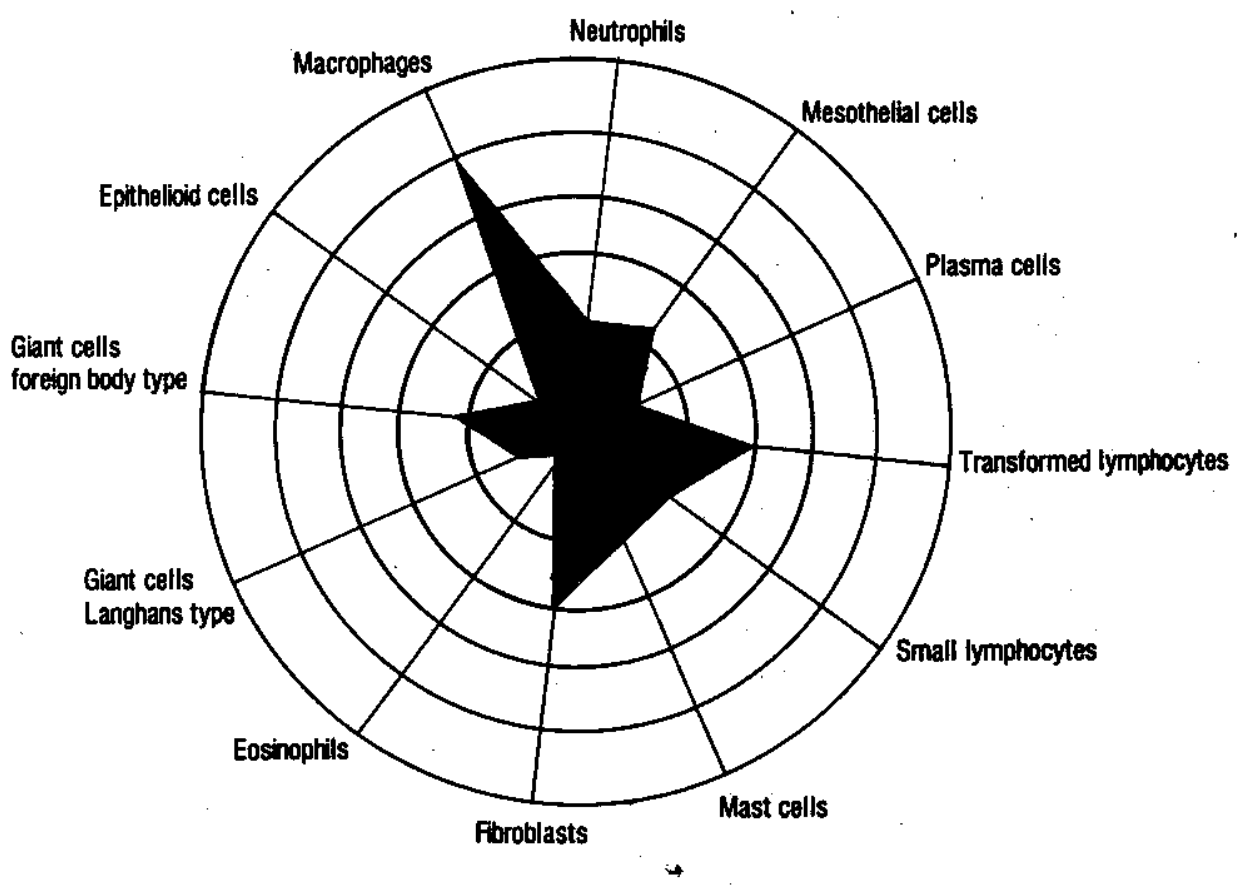

Figure 9 - Schematic of the presence of major cellular elements at the pre-granulomatous stage of infection.

granulomas; or, they could have been formed in lymphocyte-abundant areas, by the stimulus of lymphokines of the interferon type ${ }^{37}$, or by lymphocyte proteins which determine cellular fusion ${ }^{31}$.

The increase of plasmocytosis as the lesions became chronic may have been caused by antigenic stimuli which arose-from successive surges of new parasites. The role of the anti-P. brasiliensis antibodies in limiting fungal proliferation in host tissue or in modifying the inflammatory process is uncertain. BIAGIONI et al. ${ }^{3}$ suggest that IgG and $\mathrm{C}_{3}$ played an early and important role in host defense against $\mathbf{P}$. brasiliensis, cooperating with the organization and fungicidal activity of the granuloma. The specific antibodies would bind to the fungi, blocking the antigenic diffusion, activating the complement system, and helping in the destruction of parasites through phagocytosis or lysis. Other studies suggest that anti-P. brasiliensis antibodies limit fungal proliferation within the host tissue or modify the type of inflammatory cells which take part in the histopathologic picture of infected organs, and relate serological results to severity of the disease 4,11 .

However, our findings do not show that plasma cells are effective in protection against infection for even the granulomas rich in these cells contained parasites in proliferation, although circumscribed.

It is known that mast cells may actively participate in immunoregulation, fibrogenesis, tissue repair, and angiogenesis $2,5,12,13$; however, the rather constant presence of these cells in the development of our infection did not allow us to relate them specifically to any of the above processes.

Synthesis of the extracellular matrix increased gradually, especially in the 
KERR, I.B.; ARARIPE, J.R.; OLIVEIRA, P.C. \& LENZI, H.L. - Paracoccidioidomycosis: a sequential histopathologic study of lesions in experimentally-infected rats. Rev. Inst. Med. trop. SEo Paulo, 30(5):336-350, 1988.

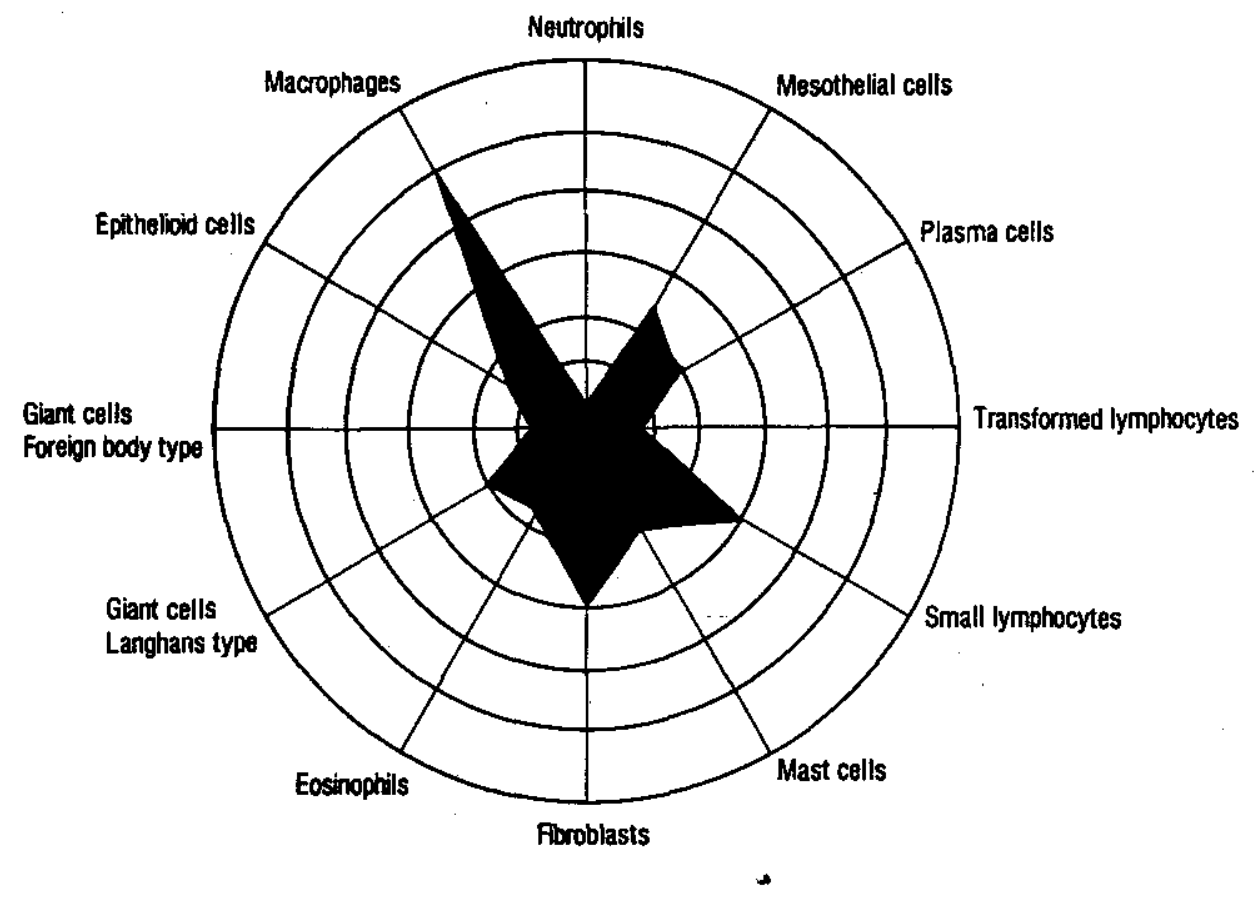

Figure 10 - Schematic of the presence of major cellular eiements at the granulomatous stage of iniection.

granulomatous stage and thereafter, due to deposits of collagen as well as of proteoglycans and glycoproteins, and it started with the deposition of fibrin-like material as early as the neutrophilic stage, imitating the sequence of components of the matrix as seen in repair.

During their development, the granulomas displayed their own extracellular matrix, made up of sulfated and acid proteoglycans, collagen types I and III, and reticular fibers.

The reticular fibers in net-like pattern around the granulomas seen at the onset of infection, and not always detected by the Picrosirius-polarization method, preceding the presence of collagen types I and III, could corresponding to other types of proteins and glycoproteins of the matrix ${ }^{39}$.

Synthesis of collagen type I was greater than that of collagen type III, and increased especially towards the end of lesion development. Our kinetic study seems to indicate that the fibrosis of the granulomas could evolve into an ever-increasing rate of collagenesis, or result in residual foci indicating collagenolysis.

Greater or smaller amounts of fibrosis could be the result of an unbalance between the collagen synthesis and degradation in the tissue, as has been suggested for schistosomiasis's4. Interactions between glycoproteins and collagen synthesized in the lesions could protect themselves against the degeneration brought about by collagenase and other proteases produced by macrophages and fjbroblasts $\mathbf{1 8 , 2 0}$.

The presence of proteoglycans seems to be fundamentally important in the configuration, movement, metabolism, and differentiation of host cells, also influencing the cellular cytoskeleton ${ }^{23}$. Proteoglycans, without a doubt, play a major part in the structural organization and functioning of the extracellular matrix.

The constant PAS positive staining noticed in the background substance along the inflammatory process, could be related to the presence of fibronectin or other glycoproteins. 
KERR, I.B.; ARARIPE, J.R.; OLIVEIRA, P.C. \& LENZI, H.L. - Paracoccidioidomycosis: a sequential histopathologic study of lesions in experimentally-infected rats. Rev. Inst. Med. trop. S.80 Peulo, 30(5):336-350, 1988.

At certain stages, we found granulomatous lesions with intense angiogenesis and which contained capillary vessels in their peripheral zone, implying that some angiogenic factor was probably being synthesized by inflammatory agents. BURGER \& VETTO' suggest that endothelial vascular cells fulfill a major role in development of the cellular immune response. Therefore, it is possible that these cells, at certain stages of the infection, may participate directly in the cellular dynamics of the granuloma, functioning as antigen-presenting cells.

In the last stages of granuloma progression, we observed the development of post-necrotic healing areas in the center of some granulomatous reactions, characterized by the substitution of necrotic tissue by a dense network of argyrophilic and collagenous fibers, and proteoglycans. These areas were practically storage rooms filled with fungi, as observed by TEIXEIRA et al. ${ }^{34}$, which may be an excellent medium for the multiplication of fungi, by favoring their growth and preventing the fungicidal action from the components of the inflammation.

Our observations show that parasitary agents possess an extraordinary ability to survive in the host tissue, even when all the conditions are hostile. This ability to survive would motivate a response by the host, who would try to balance the parasite/host relationship. Thus, after the frustrated attempt to eliminate the fungi, the host would lay siege to the parasite, thereby limiting it. In fact, the granuloma prevents the dissemination and multiplication of the parasite. This, however, continues to survive and manages to escape the state of siege, spreading throughout the organism, and resulting in recurrence and the cyclic pattern of the disease. Thus, the granulomatous process does not eliminate the disease, nor does it limit fungal dissemination. over a prolonged period of time.

\section{RESUMO}

\section{Paracoccidioidomicose: Estudo \\ Histopatológico sequencial das lesões em ratos experimentalmente infectados}

Foram utilizados ratos albinos, fêmeas, para o estudo histopatológico sequencial da paracoccidioidomicose experimental. Os animais $^{39}$ foram inoculados intraperitonealmente com uma cepa de Paracoccidioides brasiliensis na fase leveduriforme e sacrificados, em determinados intervalos, a partir de 1 a 168 dias pós-infecção; cada animal recebeu um inóculo de $4 \times 10^{6}$ células em $0,8 \mathrm{ml}$ de salina. Os animais controles receberam salina contendo raspado do meio de cultura.

Foram estudados tecidos correspondentes à área de inoculação. Analisou-se pela microscopia óptica o processo inflamatório granulomatoso em todo o seu conjunto, estudando a população celular, a matriz extracelular e a presença e características do fungo.

Os resultados possibilitaram desmembrar a cinética da resposta inflamatória em três fases: 1) neutrofílica ou macrofágica-neutrofílica; 2) pré-granulomatosa; 3) granulomatosa.

A sintese de matriz extracelular iniciou-se pela deposição de material fibrinóide, intensificando-se de modo gradativo com depósito de colágeno, de proteoglicanos e glicoproteínas. Os parasitos estavam presentes em todas as fases estudadas.

Períodos de reativação da doença eram nitidamente evidenciados através da concomitância de granulomas recém-formados com granulomas mais antigos, indicando que o processo granulomatoso neste modelo não resolve a doença, nem tão pouco consegue limitar a disseminação do fungo por um período prolongado.

\section{REFERENCES}

1. BEELEN, R.H.J.; FLUITSMA, D.M. \& HOEFSMIT, E.C.M. - The cellular composition of omentum milky spots and the ultrastructure of milky spot macrophages and reticulum cells. J. reticuloendoth. Soc., 28:585$599,1980$.

2. BEER, D.J.; MATLOFF, S.M. \& ROCKLIN, R.E. The influence of histamine on immune and inflammatory response. Advanc. Immunol., 35:209-268, 1984.

3. BIAGIONI, L.M.V.; ORSI, S.; CHAMMA, L.G.; SADATSUNE, T. \& FRANCO, M. - Imunoglobulinas e $\mathrm{C}_{3}$ no granuloma paracoccidibidico. Rev. Inst. Med. trop. S. Paulo, 29:97-103, 1987.

4. BIAGIONI, L.; SOUZA, M.J.; CHAMMA, L.G.; MENDES, R.P.; MARQUES, S.A.; MOTA, N.G.S. \& FRANCO, M. - Serology of paracoccidioidomycosis. II. Correlation between class-specific antibodies and clinical forms of the disease. Trans. roy. Soc. trop. Med. Hyg., 78:617-621, 1984.

5. BJERMER, L.; ENGSTRÖM-LAURENT, A.; THUNELL, M. \& HÄLLGREN, R. - The mast cell and 
KERR, I.B.; ARARIPE, J.R.; OLIVEIRA, P.C. \& LENZI, H.L. - Paracoccidioidomycosis: a sequential histopathologic study of lesions in experimentally-infected rats. Rev. Inst. Med. trop. Sao Paulo, 30(5):336-350, 1988.

signs of pulmonary fibroblast activation in sarcoidosis. Int. Arch. Allergy, 82:298-301, 1987.

6. BRITO, T. \& FAVA NETTO, C. - Disseminated experimental South American blastomycosis of the Guinea pig; a pathologic and immunologic study. Path. et Microbiol. (Basel), 26:29-43, 1963.

7. BURGER, D.R. \& VETTO, R.M. - Hypothesis. Vascular endothelium as a major participant in $T$ lymphocyte immunity. Cell. Immunol., 70:357-361, 1982.

8. CALICH, V.L.G.; KIPNIS, T.L.; MARIANO, M.; FAVA-NETO, C. \& DIAS DA SILVA, W. - The activation of the complement system by Paracoccidioides brasiliensis in vitro: its opsonic effect and possible significance for an in vivo model of infection. Clin. Immunol. Immunopath., 12:20-30, 1979.

9. CALICH, V.L.G.; VAZ, C.A.C. \& BURGER, E. PMN chemotactic factor produced by glass-adherent cells in the acute inflammation caused by Paracoccidioides brasiliensis. Brit. J. exp. Patb., 66:57-65, 1985.

10. CARSON, F.L.; MARTIN, J.H. \& LYNN, J.A. Formalin fixation for electron microscopy. A reevaluation. Amer. J. clin. Path., 59:365-373, 1973.

11. CARVALHAES, M.S.; SILVA, W.D.; BIRMAN, E.G.; SANT'ANNA, O.A.; ABRAHAMSOHN, P. \& LIBERMAN KIPNIS, T. - Experimental paracoccidioidomycosis in high and low antibody-producer mice. 1. Evolution of the disease, its correlation with the humoral immune response and the patterns of tissue lesions. Ann. Immunol. (Paris), Serie C, 137C:127-141, 1986.

12. CLAMAN, H.N. - Mast cell, T cells and abnormal fibrosis, Immunol. Todny, 6:192-196, 1985.

13. DEXTER, T.M.; STODDART, R.W. \& QUAZZAZ, S.T.A. - What are mast cells for? Nature, 291:110 $111,1981$.

14. DUNN, M.A. - Liver fibrosis in schistosomiasis. In: SLUTZKY, G.M., ed. - The Biochemistry of parasites. New York, Pergamon Press, 1980. p. 191-199.

15. FREUNDLICH, B.; BOMALASKI, J.S.; NEILSON, E. \& JIMENEZ; S.A. - Regulation of fibroblast proliferation and collagen synthesis by cytokines. Immunol. Today, 7:303-307, 1986.

16. GOIHMAN-YAHR, M.; ESSENFELD-YAHR, E.; ALBORNOZ, M.C.; YARZÁBAL, L.; GÓMEZ, M.H.; SAN MARTIN, B.; OCANTO, A.; GIL, F. \& CONVIT, J. - Defect of in vitro digestive ability of polymorphonuclear leukocytes in paracoccidioidomycosis. Infect. Immun., 28:557-566, 1980.

17. IABUKI, K. \& MONTENEGRO, M.R. - Experimental paracoccidioidornycosis in the Syrian hamster: Morphology, ultrastructure and correlation of lesions with presence of specific antigens and serum levels of antibodies. Mycopathologia (Den Haag), 67:131-141, 1979.

18. JONES, P.A. \& WERB, Z. - Degradation of connective tissue matrices by macrophages. II. Influence of matrix composition on proteolysis of glycoproteins, elastin, and collagen by macrophages in culture. J. exp. Med., 152:1527-1536, 1980.
19. JUNQUEIRA, L.C.U.; BIGNOLAS, G. \& BRENTANI, R.R. - Picrosirius staining plus polarization microscopy, a specific method for collagen detection in tissue sections. Histochem. J., 11:447-455, 1979.

20. JUNQUEIRA, L.C.U. \& MONTES, G.S: - Biology of collagen-proteoglycan interaction. Arch. histol. jap., 46:589-629, 1983.

21. KERR, I.B.; OLIVEIRA, P.C. \& SCHAEFFER, G.V. - Influence of inoculum size on the development of intraperitoneal paracoccidioidomycosis in rats. $\mathbf{J}$. infect. Dis., 149:821, 1984.

22. KERR, I.B.; SCHAEFFER, G.V. \& MIRANDA, D.S - Sex hormones and susceptibility of the rat to paracoccidioidomycosis. Mycopathologia (Den Haag), 88:149-154, 1984.

23. KUETTNER, K.E. \& KIMURA, J.H. - Proteoglycans: an overview. J. cell. Biochem., 27:327-336, 1985.

24. LENNERT, K. - Malignant lymphomas other than Hodgkin's disease. Berlin, Springer-Verlag, 1978. p. 77.

25. LINARES, L.I. \& FRIEDMAN, L. - Experimental paracoccidioidomycosis in mice. Infect. Imman., 5:681-687, 1972.

26. MACKINNON, J.E. - Pathogenesis of South American Blastomycosis. Trans. roy. Soc. trop. Med. Hyg., 53:487-494, 1959.

27. MCEWEN, J.G.; BRUMMER, E.; STEVENS, D.A. \& RESTREPO, A. - Effect of murine polymorphonuclear leukocytes on the yeast form of Paracoccidioides brasiliensis. Amer. J. trop. Med. Hyg., 36:603-608, 1987

28. MCEWEN, J.G.; SUGAR, A.M.; BRUMMER, E.; RESTREPO, A. \& STEVENS, D.A. - Toxic effect of products of oxidative metabolism on the yeast form of Paracoccidioides braslliensis. J. med. Microbiol. 18:423-428, 1984.

29. MOSCARDI, M. \& FRANCO, M.F. - Paracoccidioidomicose experimental do camundongo. II- Infeccăo intraperitoneal após sensibilizaçåo prévia. Rev. Inst. Med. trop. S. Paulo, 23:204-211, 1981

30. PERAÇOLI, M.T.S.; MOTA, N.G.S. \& MONTENE GRO, M.R. - Experimental paracoccidioidomycosis in the Syrian hamster. Morphology and correlation of lesions with humoral and cell-mediated immunity. Mycopathotogia (Den Haag), 79:7-17, 1982.

31. POSTLETHWAITE, A.E.; JACKSON, B.K; BEA CHEY, E.H. \& KANG, A.H. - Formation of multinucleated giant cells from human monocyte percursors J. exp. Med., 155:168-178, 1982.

32. RESTREPO, A. \& VELEZ, H. - Efectos de la fagocitosis in vitro sobre el Paracoceldioides brasiliensis. Sabouraudia, 13(part 1):10-21, 1975.

33. SCHWARTZ, L.B \& AUSTEN, K.F - Structure and function of the chemical mediators of mast cells. Progr. Allergy, 34:271-321, 1984.

34. TEIXEIRA, G.A.; MACHADO FILHO, J. \& MIRANDA, J.L. - Blastomicose sul-americana experimental. Estudo experimental em ratos com consideraçoes relativas à patogenia das lesōes. Hospital (Bio de J.), 68:1081-1096, 1965 . 
KERR, I.B.; ARARIPE, J.R.; OLIVEIRA, P.C. \& LENZI, H.L. - Paracoccidioidomycosis: a sequential histopathologic study of lesions in experimentally-infected rats. Rev. Inst. Med. trop. Säo Paulo, 30(5):336-350, 1988.

35. TURK, J.L. \& NARAYAMA, R.B. - The origin, morphology, and function of epithelioid cells. Immunobiology, 161:274-282, 1982.

36. WAHL, S.M. \& WAHL, L.M. - Modulation of fibroblast growth and function by monokines and lymphokines. Lymphokine Res., 2:179-201, 1981.

37. WEINBERG, J.B.; HOBBS, M.M. \& MISUKONIS, M.A. - Recombinant human-interferon induces human monocyte polykaryon formation. Proc. nat. Acad. Sci. (Wash.), 81:4554-4557, 1984.
38. WHITAKER, D, \& PAPADIMITRIOU, J, - Mesothelial healing: morphological and kinetic investigations. J. Path., 145:159-175, 1985.

39. WOLMAN, M. \& KASTEN, F.H. - Polarized light microscopy in the study of the molecular structure of collagen and reticulin. Histochemistry, 85:41-49, 1986.

Recebido para publicação em 10/3/1988. 